\title{
ANALYTICAL STUDY OF THE STATIC THERMOMECHANICAL STRESSES OF THE ASSEMBLIES WITH OPTIONAL RING FLANGES. ROTATION OF THE FLANGE RING AROUND THE CIRCUMFERENCE OF CENTERS FOR BOLT HOLES
}

\author{
RADU I. IATAN ${ }^{* 1}$, GHEORGHITA TOMESCU ${ }^{1}$, GEORGETA ROMAN (URSE) ${ }^{1}$, \\ MELANIA CORLECIUC (MITUCA) ${ }^{1}$, IOLANDA CONSTANTA PANAIT ${ }^{1}$ \\ ${ }^{1}$ Faculty of Mechanical and Mechatronics Engineering, Industrial Process Equipment \\ Department, POLITEHNICA University of Bucharest, Bucharest, 060042, Romania
}

\begin{abstract}
This paper addresses the evaluation of thermal and mechanical stresses that occur in assemblies with flat ring flanges, of optional type. The flange rings are fixed by welding to the wall of the cylindrical body of the vessel, with a constant thickness along its length. Regarding of the above, the compatibility of the deformations of the component elements (radial displacements and rotations) is approached. A linear algebraic system is formed in which both external loads (pressure, temperature) and connecting loads (bending unit moments and unit forces) are present. The present analysis discusses the quantitative, cumulative effect of the deformed gasket and the stiffness of the curved/bent screws on the tightness of the system. The methodology is flexible by introducing selection factors so that the mentioned influences can be easily separated.
\end{abstract}

Keywords: circular flat flange assemblies, stresses, deformations

\section{INTRODUCTION}

The growing need to chemically or mechanically process various chemicals has led to the creation of complex mechanical equipment that can withstand low or high working parameters. In this context, a very important role is taken by the sealing of liquid or gaseous substances processed in static or dynamic equipment, for chemical and/or mechanical processing. The practical constructive types are particularly diverse: flat or neck ring flanges [1 - 39], respectively ring flanges with radial ribs [40 - 46], tightened with screws, with clips or with clamps [47 50], with ring seals flat [51 - 53] or lenticular [54 - 56], respectively without gaskets [57 - 60]). The choice of the material of a sealing gasket is a difficult problem, because it must meet a number of extremely important conditions, such as: a) be stable at working temperature, pressure and chemical and mechanical aggressiveness of the technological environment, while maintaining its economic characteristics; c) have resistance to friction and wear; e) deform elastoplastic, when the gasket is tight, in order to completely fill the micro-asperities of the sealing surfaces. For its importance, recognized experimental research has been carried out over time [61 - 67], as well as appropriate theoretical studies $[39,68,69]$, for example, for the evaluation of the sealing pressure between the flange rings, in the radial and circumferential direction.

In this sense, the study of flange assemblies can be performed taking into account static and/or dynamic loads, simple or combined (pressures, temperatures, transient regime, fatigue, creep, earthquake) [70 - 79], as well as corrosive and/or erosive aggression for metallic or non-metallic materials (polymeric or composite). The theoretically established mathematical expressions clearly show the influence of the rigidity of the assembly on

\footnotetext{
* Corresponding author, email: iatan.radu@gmail.com

(C) 2021 Alma Mater Publishing House
} 
the tightness, the reason for which, as much as possible, a diametric gauge of the ring as small as possible is imposed, simultaneously with the increase of its thickness. In the same sense, the possible increase in the number of tightening screws is sought. All the elements mentioned above have in view, simultaneously, the assurance of a safe operation, in specific conditions, but also the existence of a minimum consumption of construction material, in this case the lowest possible price of construction material, but also of labor and maintenance.

\section{STUDY HYPOTHESES}

The following analytical study considers the following simplifying hypotheses:

1. The rings of the flat flanges are fixed to the cylindrical shell (with constant thickness) by welding (Figure 1); the cylindrical shell adjacent to the flange ring, along its entire thickness, is considered to have length $\mathrm{h}_{c}<\ell_{s c} \approx 1.77 \cdot \sqrt{D_{m c} \cdot \delta}$, to use the theory of short structural elements; the thickness of the cylindrical shell is accepted constant throughout the deformation;

2. An assembly with flanges (rings) identical in terms of geometry (flat plates) and material is considered;

3. The effect of the welding cords for fixing the cylindrical ferrule with the flange ring on the general state of stress is neglected;

4. The metallic material of the assembly components is considered homogeneous, continuous and isotropic, required in the elastic field;

5. External loads (pressure, temperature) have static values;

6. Deformation of the rings in the radial direction and their rotation, according to the accepted hypothesis, is performed in a monobloc configuration; the effect of the screw holes on the rigidity of the flange ring is neglected;

Note: The rotation of the flange ring, in this case, occurs around the circumference of the centers of the screw holes, defined by the diameter $D_{s}$ (Figure 1).

7. The value of the rotation angle of the flange ring is conditioned by the intensity of the internal connection loads, together with the effect of the external loads: a) the unit force resistant to the tendency of the expulsion of the gasket $[27,39]$; b) by the bending, resistant unit moments, $m_{g}$, by the eccentric compression of the gasket, respectively $\mathrm{m}_{\mathrm{s}}$ present due to the curvature of the screws [7, 9, 40 - 42], all related to the inner circumference of the ring;

8. A uniform radial compression of the gasket for sealing and, at the same time, an identical tightening of the screws, by using a specific methodology and suitable systems is considered [31, 35, 80-82];

9. Accepting the ring of a flange as a flat ring plate, with a constant thickness over its entire width, simply supported along the circumference of the screw centers, characterized by the diameter (Figure 1), and by the loads mentioned in point 7 (above), sets the following expression for the angle of rotation (around points C - Figure 2):

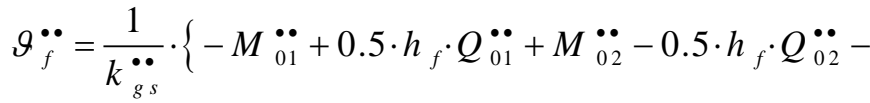

$$
\begin{aligned}
& -0.5 \cdot\left[\left(D_{2}-D_{i f}\right) \cdot\left(D_{2} / D_{i f}\right)+\mu_{f g} \cdot h_{f} \cdot c_{\vartheta}^{f g}\right] \cdot \bar{P}_{2}+0.5 \cdot\left(D_{s}-D_{i f}\right) \cdot \bar{P}_{s}- \\
& \left.-0.5 \cdot\left[\left(D_{m g}-D_{i f}\right) \cdot\left(D_{m g} / D_{i f}\right)+\mu_{f g} \cdot h_{f} \cdot c_{\vartheta}^{f g}\right] \cdot \bar{P}_{g}\right\} \text {, }
\end{aligned}
$$

where: 


$$
\begin{gathered}
k_{g s}^{\ddot{g}}=\frac{1}{k_{f} \cdot}+\frac{n_{s} \cdot E_{s} \cdot d_{s}^{4} \cdot D_{i} \cdot c_{\vartheta}^{s}}{\left(6 \cdot \ell_{s} \cdot D_{s}^{2}\right)}+\frac{E_{g} \cdot c_{g}^{3} \cdot D_{m g} \cdot\left(D_{e g}-D_{i g}\right)^{3} \cdot D_{i f} \cdot c_{\vartheta}^{g}}{\left(48 \cdot h_{g} \cdot D_{m g}\right)} \\
k \ddot{f}=0.5 \cdot D_{s}^{2} \cdot \frac{\left[1-v_{f}+\left(1+v_{f}\right) \alpha_{D f}\right]}{\left[\alpha_{D f} \cdot\left(\alpha_{D f}^{2}-1\right) \cdot\left(1-v_{f}^{2}\right) \cdot \Re_{f} \cdot D_{i f}\right]} \\
\alpha_{D f}=\frac{D_{s}}{D_{i f}}
\end{gathered}
$$

From the expression of the continuity of the deformations it is found that the effects of the previously mentioned quantities lead to the diminution of the total rotation of the flange ring, favoring the tightness of the assembly.

In the structure of factor $k_{g s}^{\bullet}$ the selection factors $\mathrm{c}_{\vartheta}^{g}, \mathrm{c}_{\vartheta}^{s}, \mathrm{c}_{\vartheta}^{f g}$ are introduced, allowing to easily notice the influences of the "resisting" quantities to the deformation of the flange ring (when the mentioned coefficients take values equal to unity, the influences are present; when the values are zero, those influences disappear).

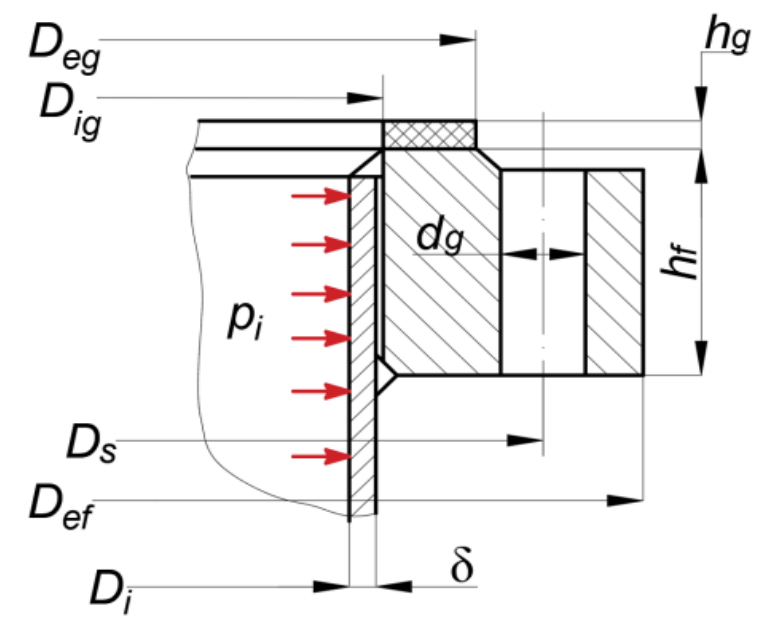

Fig. 1. Ring flat flange type A (dimensional characteristics - diagram).

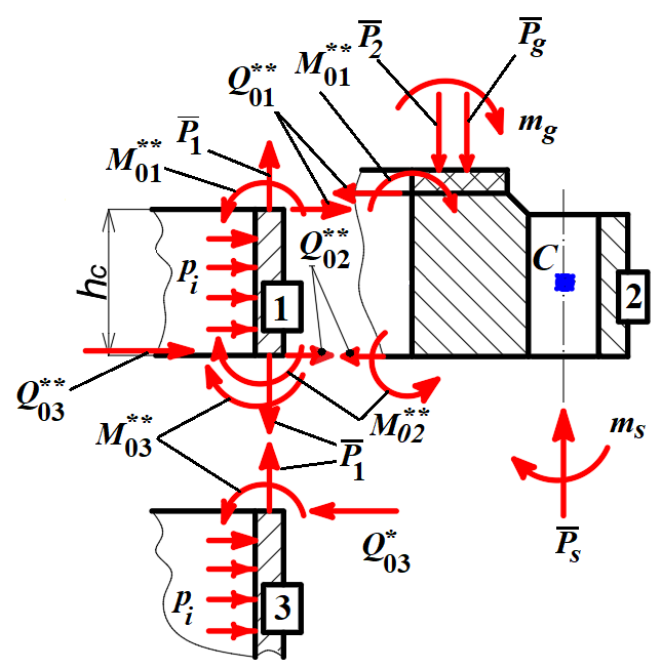

Fig. 2. Decomposition (hypothetical) of flange assembly elements (diagram):

1 - cylindrical shell adjacent to the flange ring; 2 - flange ring; 3 - cylindrical shell (vessel body). 


\section{ANALYTICAL STUDY. CONNECTION LOADS}

To establish the expressions of the unitary bending moments and of the unitary connecting forces, the assembly is decomposed (fictitiously) into the component elements (Figure 2). In this sense, the equations of compatibility of deformations between the elements mentioned above are written as follows:

connection between elements 1 - 2 (top):

- radial displacements:

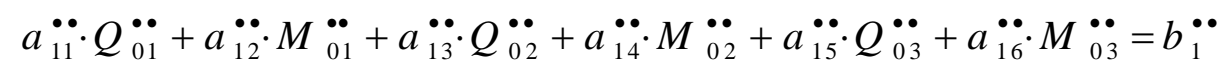

- rotations:

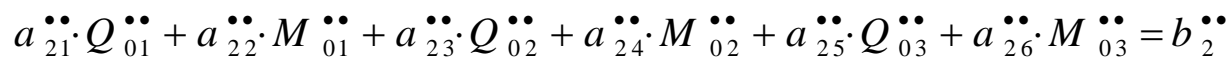

connection between elements 1 - 2 (bottom):

- radial displacements:

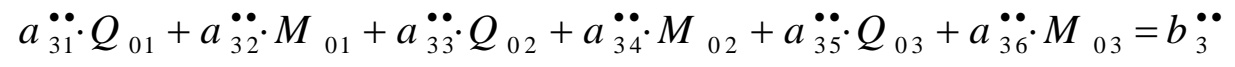

- rotations:

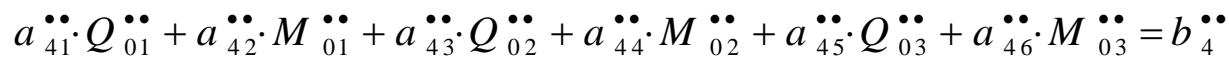

connection between elements $1-3$ :

- radial displacements

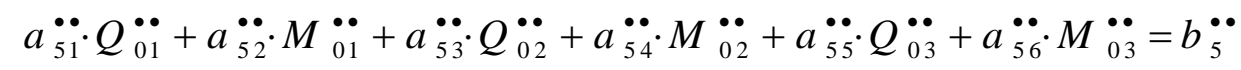

- rotations:

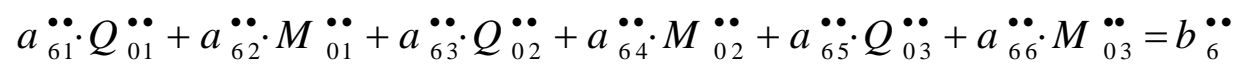

Equalities (4) - (9) form the algebraic system written in the form:

$$
\left[A^{\bullet \cdot}\right] \cdot\left\{S_{\ddot{l}}^{\bullet}\right\}=\left\{T_{\ddot{l}}^{\bullet}\right\}
$$

where:

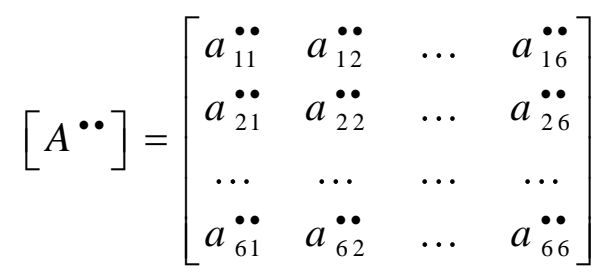

represents the matrix of influencing factors $a_{i j} \ddot{i}(i=1 \cdots 6 ; j=1 \cdots 6)$; the transposed vector of the connection load.

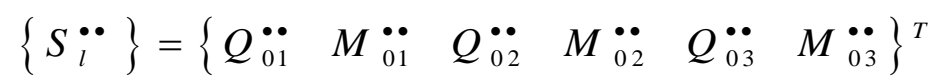


transposed vector of free terms (radial displacements and rotations under the action of external loads - pressure, temperature):

$$
\left\{T_{i}^{\bullet}\right\}=\left\{\begin{array}{llll}
b_{1}^{\bullet} & b_{2}^{\bullet} & \ldots & b_{6}^{\bullet \bullet}
\end{array}\right\}^{T}
$$

From equality (9) the way of evaluating the values of the unknowns of the present problem - unitary shear forces $Q_{0 k}^{\ddot{*}}(k=1 \cdots 3)$ and unitary bending moments $M_{0 k}^{\bullet}(k=1 \cdots 3)$ is deduced- written in the form

$$
\left\{S_{\ddot{l}}^{\bullet}\right\}=\left[A^{\bullet}\right]^{-1} \cdot\left\{T_{\ddot{l}}^{\bullet}\right\}
$$

where $\left[A^{\bullet \cdot}\right]^{-1}$ represents the inverse of the $\left[A^{\bullet}\right]$ matrix, whose determinant has a value other than zero.

The expressions of the influencing factors from the equalities (4) - (9) have the forms:

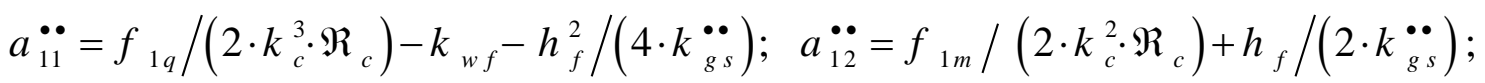

$$
\begin{aligned}
& a_{13}^{\ddot{\bullet}}=f_{q d}\left(h_{c}\right) /\left(2 \cdot k_{c}^{3} \cdot \Re_{c}\right)-k_{w f}+h_{f}^{2} /\left(4 \cdot k_{g s} \ddot{g}^{\prime}\right) \text {; } \\
& a_{14} \ddot{=} f_{m d}\left(h_{c}\right) /\left(2 \cdot k_{c}^{2} \cdot \Re_{c}\right)-h_{f} /\left(2 \cdot k_{g s}^{\bullet}\right) ; a_{15}=f_{q d}\left(h_{c}\right) /\left(2 \cdot k_{c}^{3} \cdot \Re_{c}\right) \text {; } \\
& a_{16}=f_{m d}\left(h_{c}\right) /\left(2 \cdot k_{c}^{2} \cdot \Re_{c}\right) ; a_{21}^{\ddot{*}}=-f_{23 q} /\left(2 \cdot k_{c}^{2} \cdot \Re_{c}\right)-h_{f} /\left(2 \cdot k_{g s}\right) \text {; }
\end{aligned}
$$

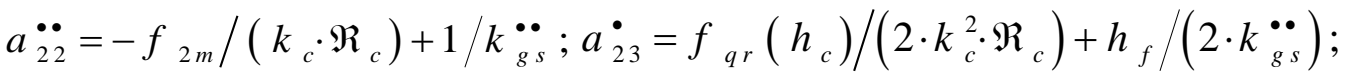

$$
\begin{aligned}
& a_{24} \ddot{2}=f_{m r}\left(h_{c}\right) /\left(2 \cdot k_{c} \cdot \Re_{c}\right)-1 / k_{g s} \ddot{g}_{25} a_{\ddot{25}}=f_{q r}\left(h_{c}\right) /\left(2 \cdot k_{c}^{2} \cdot \Re_{c}\right) \text {; } \\
& a_{26}^{\ddot{*}}=f_{m r}\left(h_{c}\right) /\left(2 \cdot k_{c} \cdot \Re_{c}\right) ; a_{31}^{\ddot{*}}=f_{q d}\left(h_{c}\right) /\left(2 \cdot k_{c}^{3} \cdot \Re_{c}\right)-k_{w f}+h_{f} /\left(4 \cdot k_{g s} \ddot{\bullet}\right) \text {; } \\
& a_{32}^{\ddot{*}}=f_{m d}\left(h_{c}\right) /\left(2 \cdot k_{c}^{2} \cdot \Re_{c}\right)-h_{f} /\left(2 \cdot k_{g s}^{\bullet}\right) \text {; }
\end{aligned}
$$

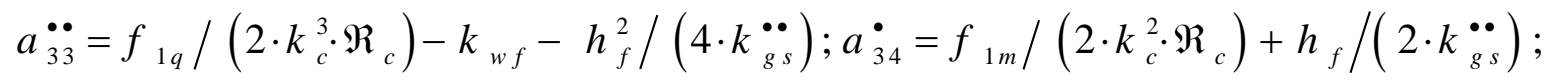

$$
\begin{aligned}
& a_{35}^{\ddot{\bullet}}=f_{1 q} /\left(2 \cdot k_{c}^{3} \cdot \Re_{c}\right) ; a_{36} \ddot{B}_{1 m} /\left(2 \cdot k_{c}^{2} \cdot \Re_{c}\right) ; \\
& a_{41}^{\ddot{\bullet}}=f_{q r}\left(h_{c}\right) /\left(2 \cdot k_{c}^{2} \cdot \Re_{c}\right)-h_{f} /\left(2 \cdot k_{g s}^{\bullet}\right) ; a_{42}=f_{m r}\left(h_{c}\right) /\left(2 \cdot k_{c} \cdot \Re_{c}\right)+1 / k_{g s}^{\bullet} \text {; } \\
& a_{43}^{\ddot{\bullet}}=-f_{23 q} /\left(2 \cdot k_{c}^{2} \cdot \Re_{c}\right)+h_{f} /\left(2 \cdot k_{g s}^{\bullet \bullet}\right) \text {; } \\
& a_{44}^{\ddot{\bullet}}=-f_{2 m} /\left(k_{c} \cdot \Re_{c}\right)-1 / k_{g s}^{\ddot{g}} ; a_{45}^{\ddot{\bullet}}=-f_{23 q} /\left(2 \cdot k_{c}^{2} \cdot \Re_{c}\right) \text {; } \\
& a_{46}^{\ddot{4}}=-f_{2 m} /\left(k_{c} \cdot \Re_{c}\right) ; a_{51}^{\ddot{*}}=f_{q d}\left(h_{c}\right) /\left(2 \cdot k_{c}^{3} \cdot \Re_{c}\right) \text {; } \\
& a_{52}^{\cdot}=f_{m d}\left(h_{c}\right) /\left(2 \cdot k_{c}^{2} \cdot \Re_{c}\right) ; a_{53}^{\bullet}=f_{1 q} /\left(2 \cdot k_{c}^{3} \cdot \Re_{c}\right) ; a_{54}^{\cdot}=f_{1 m} /\left(2 \cdot k_{c}^{2} \cdot \Re_{c}\right) ; \\
& a_{55}^{\cdot}=\left(f_{1 q}-1\right) /\left(2 \cdot k_{c}^{3} \cdot \Re_{c}\right) ; a_{56}^{\cdot \bullet}=\left(f_{1 m}-1\right) /\left(2 \cdot k_{c}^{2} \cdot \Re_{c}\right) \text {; } \\
& a_{61}^{\ddot{*}}=f_{q r}\left(h_{c}\right) /\left(2 \cdot k_{c}^{2} \cdot \Re_{c}\right) ; a_{62}^{\ddot{*}}=f_{m r}\left(h_{c}\right) /\left(2 \cdot k_{c} \cdot \mathfrak{R}_{c}\right) \text {; } \\
& a_{63}^{\ddot{*}}=-f_{23 q} /\left(2 \cdot k_{c}^{2} \cdot \mathfrak{R}_{c}\right) ; \quad a_{64}^{\cdot}=-f_{2 m} /\left(k_{c} \cdot \mathfrak{R}_{c}\right) \text {; } \\
& a_{65}^{\ddot{*}}=\left(1-f_{23 q}\right) /\left(2 \cdot k_{c}^{2} \cdot \Re_{c}\right) ; a_{66}=\left(1-f_{2 m}\right) /\left(k_{c} \cdot \Re_{c}\right) \text {, }
\end{aligned}
$$

while the vectors of radial displacements and rotations have the configurations: 


$$
\begin{aligned}
& b_{1}^{\ddot{1}}=\left[p_{i} /\left(4 \cdot k_{c}^{4} \cdot \Re_{c}\right)\right] \cdot\left[1-\mu_{c} \cdot D_{i}^{2} /\left(2 \cdot D_{m c}^{2}\right)\right]+0,5 \cdot \alpha_{c} \cdot D_{m c} \cdot \Delta T_{c}+ \\
& +\left[h_{f} /\left(4 \cdot k_{g s}\right)\right] \cdot\left\{-\left[\left(D_{2}-D_{i f}\right) \cdot\left(D_{2} / D_{i f}\right)+\mu_{f g} \cdot h_{f} \cdot c_{g}^{f g}\right] \cdot \bar{P}_{2}+\right. \\
& \left.+\left(D_{e f}-D_{s}\right) \cdot \bar{P}_{s}-\left[\left(D_{m g}-D_{i f}\right) \cdot\left(D_{m g} / D_{i f}\right)+\mu_{f g} \cdot h_{f} \cdot c_{g}^{f g}\right] \cdot \bar{P}_{g}\right\}- \\
& -\Delta R\left(\Delta T_{f}\right)_{D=D_{i f}} \text {; } \\
& b_{2}^{\ddot{2}}=\left[1 /\left(2 \cdot k_{g s}^{\ddot{g}}\right)\right] \cdot\left\{-\left[\left(D_{2}-D_{i f}\right) \cdot\left(D_{2} / D_{i f}\right)+\mu_{f g} \cdot h_{f} \cdot c_{g}^{f g}\right] \cdot \bar{P}_{2}+\right. \\
& \left.+\left(D_{s}-D_{i f}\right) \cdot \bar{P}_{s}-\left[\left(D_{m g}-D_{i f}\right) \cdot\left(D_{m g} / D_{i f}\right)+\mu_{f g} \cdot h_{f} \cdot c_{g}^{f g}\right] \cdot \bar{P}_{g}\right\} ; \\
& b_{3}^{\ddot{*}}=\left[p_{i} /\left(4 \cdot k_{c}^{4} \cdot \Re_{c}\right)\right] \cdot\left[1-\mu_{c} \cdot D_{i}^{2} /\left(2 \cdot D_{m c}^{2}\right)\right]+0,5 \cdot \alpha_{c} \cdot D_{m c} \cdot \Delta T_{c}- \\
& -\left[h_{f} /\left(4 \cdot k_{g s}^{\cdot \bullet}\right)\right] \cdot\left\{-\left[\left(D_{2}-D_{i f}\right) \cdot\left(D_{2} / D_{i f}\right)+\mu_{f g} \cdot h_{f} \cdot c_{\vartheta}^{f g}\right] \cdot \bar{P}_{2}+\right. \\
& \left.-\left[\left(D_{m g}-D_{i f}\right) \cdot\left(D_{m g} / D_{i f}\right)+\mu_{f g} \cdot h_{f} \cdot c_{\vartheta}^{f g}\right] \cdot \bar{P}_{g}+\left(D_{s}-D_{i f}\right) \cdot \bar{P}_{s}\right\}- \\
& -\Delta R\left(\Delta T_{f}\right)_{D=D_{i f}} \text {; } \\
& b_{4}^{\ddot{*}}=\left[1 /\left(2 \cdot k_{g s}^{\ddot{g}}\right)\right] \cdot\left\{-\left[\left(D_{2}-D_{i f}\right) \cdot\left(D_{2} / D_{i f}\right)+\mu_{f g} \cdot h_{f} \cdot c_{\vartheta}^{f g}\right] \cdot \bar{P}_{2}+\right. \\
& \left.+\left(D_{s}-D_{i f}\right) \cdot \bar{P}_{s}-\left[\left(D_{m g}-D_{i f}\right) \cdot\left(D_{m g} / D_{i f}\right)+\mu_{f g} \cdot h_{f} \cdot c_{\vartheta}^{f g}\right] \cdot \bar{P}_{g}\right\} ; \\
& b_{5}^{\ddot{*}}=0 ; b_{6}^{\bullet \bullet}=0
\end{aligned}
$$

In the above equations the auxiliary values (the corresponding geometric characteristics are noted in Figures 1 and 2) are found:

$$
\begin{gathered}
P_{1}=0.25 \cdot \pi \cdot D_{e c}^{2} \cdot p_{i} ; \bar{P}_{1}=P_{1} /\left(\pi \cdot D_{m c}\right) ; P_{2}=0.25 \cdot \pi \cdot\left(D_{m g}^{2}-D_{e c}^{2}\right) \cdot p_{i} ; \\
\bar{P}_{2}=0.5 \cdot\left(D_{m g}-D_{e c}\right) \cdot p_{i} ; P_{g}=0.25 \cdot \pi \cdot\left(D_{e g}^{2}-D_{i g}^{2}\right) \cdot p_{s g} ; D_{e c}=D_{i}+2 \cdot \delta ; \\
\bar{P}_{g}=0.5 \cdot\left(D_{e g}-D_{i g}\right) \cdot p_{s g} ; \Re_{c}=E_{c} \cdot \delta^{3} / \sqrt{12 \cdot\left(1-\mu_{c}^{2}\right)} ; k_{c}=\sqrt[4]{12 \cdot\left(1-\mu_{c}^{2}\right)} / \sqrt{D_{m c} \cdot \delta} ; \\
D_{m c}=D_{i}+\delta ; D_{m g}=0.5 \cdot\left(D_{i g}+D_{e g}\right) ; D_{m f}=0.5 \cdot\left(D_{i f}+D_{e f}\right) ; \\
k_{w f}=0.5 \cdot D_{i f} \cdot\left[\left(1-\mu_{f}\right) \cdot D_{e f}^{2}-\left(1-2 \cdot \mu_{f}\right) \cdot D_{i f}^{2}\right] /\left[h_{f} \cdot E_{f} \cdot\left(D_{e f}^{2}-D_{i f}^{2}\right)\right]
\end{gathered}
$$

where $E_{c}, E_{f}, E_{g}, E_{s}$ - the modules of longitudinal elasticity of the materials of the cylindrical shell, of the flange ring, of the sealing gasket, respectively of the screws material, $\mathrm{N} / \mathrm{mm}^{2}$;

$\bar{F}_{f g}=\mu_{f g} \cdot\left(\bar{P}_{g}+\bar{P}_{2}\right)$ - unitary friction force between flange ring and sealing gasket, N/mm; $\mathrm{P}_{\mathrm{s}}$ - the force developed in the screws of the flange assembly, in different operating conditions; $\bar{P}_{s}$ - the existing unit force on the diameter circumference $\mathrm{D}_{\mathrm{s}} ; \mathrm{c}_{\mathrm{g}}$ - the "reduction" coefficient of the initial gasket width, which can be chosen considering recommendations from the literature; $c_{\vartheta}^{g}, c_{g}^{s}, c_{\vartheta}^{f g}$ - selection factors used to store or eliminate the influence of gasket rotation, bolt rotation, respectively the friction between gasket and flange ring (accepting the value equal to zero); $\mathrm{d}_{\mathrm{s}}$ - nominal diameter of the screw, $\mathrm{mm}$; $f_{1 m}, f_{2 m}, f_{m d}\left(h_{c}\right), f_{m r}\left(h_{c}\right), f_{1 q}, f_{23 q}, f_{q d}\left(h_{c}\right), f_{q r}\left(h_{c}\right)$ - factors of influence of the connecting loads (unitary shear forces and bending unitary moments) [74]; $k_{g_{s}}^{\bullet}$ - influence factor, with significant force, of the quantities that can diminish the value of the rotation of the flange ring under the action of the loads given by the 
value of the internal pressure and of the connection loads, respectively the eccentric compression of the sealing gasket, the rotation tendency of the screws and ring, $\mathrm{N} ; \mathrm{k}_{\mathrm{wf}}$ - influencing factor the unitary shear forces (for connection) on the width of the flange ring, $\mathrm{mm}^{2} / \mathrm{N} ; 1_{\mathrm{s}}$ - calculation length of the screws, $\mathrm{mm} ; 1_{\mathrm{sc}}$ - half wavelength, $\mathrm{mm} ; \mathrm{n}_{\mathrm{s}}$ - the number of flange assembly bolts; $\mathfrak{R}_{\mathrm{c}}$ - cylindrical bending stiffness of pressure vessel body, $\mathrm{N} \cdot \mathrm{mm}$; $\Delta \mathrm{T}_{\mathrm{c}}, \Delta \mathrm{T}_{\mathrm{f}}$ - the thermal gradient of the vessel body, related to the temperature of the external environment, respectively the thermal gradient of the flange ring at its inner surface, $\mathrm{K} ; \Delta R\left(\Delta T_{f}\right)_{D=D_{i f}}$ - radial displacement of the flange ring under the influence of the thermal gradient, for the accepted law for temperature variation [75]; $\alpha_{c}, \alpha_{\mathrm{f}}$ - thermal deformation factor for cylindrical shell and for ring flange, $\mathrm{K}^{-1} ; \mu_{\mathrm{c}}, \mu_{\mathrm{f}}-$ the Poisson coefficient (of the transverse contraction) of the cylindrical shell material, the flange ring material; $\mu_{\mathrm{fg}}-$ the coefficient of friction between the sealing gasket and the flange ring.

\section{CONCLUSIONS}

Based on the previous relations, establishing the expressions of the connection loads between the considered assembly elements, hypothetically separated (Figure 2) it is possible to deduce the expression of the flange ring rotation, taking into account the equalities (1) - (3). The value of this angle provides an assessment of the tightness of the system. In an unsuitable state, the geometry of the assembly components is modified (increasing the thickness of the shell on a certain length, greater than the length of the half-wave, under the flange ring, respectively increasing the thickness of the considered flange ring).

The results of the theoretical and experimental works are known, which indicate that the state of tension is more intense along the length of the cylindrical ferrule 3 (Figure 2), below the plane of connection with the flange ring. Once the values for $Q_{03}^{\bullet \bullet}$ and $M_{03}^{\bullet}$ are known and taking into account the effects of pressure and temperature, we proceed to evaluate the variable stresses on the inner and outer surface of the shell of the cylindrical body [3, 5]. The maximum equivalent stress, established by using the 5th resistance theory, is compared with the allowable strength of the metallic material. If the resistance condition is met, the analytical study is completed. Otherwise, the geometry of the assembly is remodeled until the accepted technical safety is confirmed.

An adequate calculation program can lead to the optimization of the construction, with the minimization of the material consumption and the assurance of a safe operation. The previously exposed methodology allows, at the same time, an evaluation of the stresses and by using the discrete values of the external loads in case of a transient regime of the pressure, respectively of the temperature. The results obtained on the exposed path can be developed in further research on the behavior of flange assemblies in areas such as creep, fatigue, the effect of residual stresses in weld seams, or the prevention of cracking [83 - 86].

\section{REFERENCES}

[1] Jinescu, V.V., Teodorescu, N., Constructia si calculul imbinarilor cu flanse, Revista de Chimie, vol. 32, no. 3, 1981 , p. $286-292$.

[2] Jinescu, V.V., Teodorescu, N., Constructia si calculul imbinarilor cu flanse, Revista de Chimie, vol. 32, no. 4, 1981, p. $385-393$.

[3] Jinescu, V.V., Teodorescu, N., Constructia si calculul imbinarilor cu flanse, Revista de Chimie, vol. 33, no. 7, 1982, p. $671-676$.

[4] Jinescu, V.V., Teodorescu, N., Constructia si calculul imbinarilor cu flanse, Revista Chimie, vol. 38, no. 8, 1987, p 727-730.

[5] Jinescu, V.V., Teodorescu, N., Constructia si calculul imbinarilor cu flanse, Revista de Chimie, vol. 39, no. 1, 1988 , p. $75-77$.

[6] Jinescu, V.V., Teodorescu, N., Constructia si calculul imbinarilor cu flanse, Revista de Chimie, vol. 39, no. 2, 1988 , p. $185-188$.

[7] Iatan, I.R., Consideratii asupra calculului flanselor inelare sudate, in faza de montaj, Institutul Politehnic Bucuresti, Scientific Bulletin, Series D, vol. 53, 1981, p. $101-112$.

[8] Jinescu, V.V., Calculul si constructia utilajului chimic, petrochimic si de rafinarii, vol. 1, Ed. Tehnica, Bucuresti, 1983. 
[9] Iatan, I.R., Contributii la calculul mecanic al imbinarilor cu flanse plate inelare, sudate, Institutul Politehnic din Bucuresti, Series D, vol. 53, 1983, p. $50-60$.

[10] Jinescu, V.V., Utilaj tehnologic pentru industrii de proces, Ed. Tehnica, Bucuresti, vol. 1, 1983.

[11] Jinescu, V.V., Utilaj tehnologic pentru industrii de proces, Ed. Tehnica, Bucuresti, vol. 3, 1988.

[12] Nagy, A., Determination of the loosening coefficient at large size welding neck flange joints, Periodica Polytechnica Mechanical Engineering, vol. 38, no. 2- 3, 1994, p. 179-199.

[13] Moglo, E.K., Etude des brides boulonnees en materiaux composites, These, Universite de Montreal, Canada, 1996.

[14] Varga, L., Nagy, A., Optimale form und neue analyse von flanschkonstruktionen, Konstruktion, vol. 49, no. 9, 1997, p. 25-30.

[15] Iatan, I. R., Alamoreanu, E., Iordan N., Chirita, R., Calculus elements for ring neck flanges, Modelling and Optimization in the Machines Building Field, MOCM 3, University of Bacau, 1997, p. 14-17.

[16] Jinescu, V.V., Teodorescu, N., Metoda pentru calculul asamblarilor cu flanse, Constructia de Masini, vol. 52, no. 12,2000 , p. 1-8.

[17] Nash, H.D., Abid, M., Combined external load tests for standard and compact flanges, International Journal Pressure Vessels and Piping, vol. 77, no. 13, 2000, p. 799 - 806.

[18] GOST P 52857.4, Sosudi i apprati, Normi i metodi rascieta na procinosti, Rasciet na procinosti i ghermeticonosti flantevah soedinenii, Nationalnai Standard Rossiikoi Federatii, 2007.

[19] British Standard PD - 5500, Specification for fusion welded pressure vessels, 2009.

[20] European Standard 13445:2009, Unfired pressure vessels - Part 3: Design, 2009.

[21] Galai, H., Analyse des assemblages a brides boulonnees a face plate, These, Ecole de Technologie Superieure, Universite du Quebec, Canada, 2009.

[22] ASME Boiler and pressure vessel code, Section VIII, Division 2, Rules for construction of pressure vessels, July 01, 2010.

[23] Couchaux, M., Hjiaj, M., Ryan, I., Bureau, A., Bolted circular flange connections (Bending and axial static resistance), EUROSTEEL 2011, August 31 - September 02, Budapest, Hungary, 2011, p. 219-224.

[24] Gorla, R. S.R., Tanawade, A., Probabilistic structural and thermal analysis of a gasketed flange, Applied Thermal Engineering, vol. 59, 2013, p. 535 - 541.

[25] Kurz, H., Roos, E., Design of floating type bolted flange connections with grp flanges, International Journal of Pressure Vessels and Piping, vol. 89, 2012, p. 1 - 8.

[26] EN 1591:2014, Flanges and their joints. Design rules for gasketed circular flange connections - Part 1: Calculation, 2014.

[27] Luyt, B. C.P., A leak tight design methodology for large diameter flanges based on non - linear modelling and analysis, Thesis, Department Mechanical and Aeronautical Engineering University of Pretoria, Africa de Sud, 2015.

[28] Estrada, H., Analysis of leakage in bolted flanged joints using contact finite element analysis, Journal of Mechanics Engineering and Automation, vol. 5, no. 3, 2015, p. 135 - 142.

[29] Khan, B.N., Abid, M., Jammel, M., Wajid, A.H., Joint strength of gasketed bolted pipe flange joint under combined internal pressure plus axial load with different (industrial and ASME) bolt-up strategy, Institution of Mecahianical Engineers, Part E, Journal of Process Mechanical Engineering, 2015, p. 1 - 10.

[30] Walczak, R., Pawlicki, J., Zagorski, A., Tightness and material aspects of bolted flange connections with gaskets of nonlinear properties exposed to variable loads, Archives of Metallurgy and Materials, vol. 61, no. 3, 2016, p. 1409 - 1416.

[31] Bouzid, H.A., Beghoul, H., A new proposed method for the design of bolted joints based on flexibility and tightness, Proceedings ICPVT - 10, Vienna, Austria, 2016, p. 293 - 301.

[32] Kumar, V., Singh, P.V., Angra, S., Rani, S., Design and optimization of weld neck flange for pressure vessel, $\mathrm{V}$ th International Symposion on Fusion of Science and Technology, New Delhi, India, January 18 - 22, 2016 , p. $608-612$.

[33] Jinescu, V.V., Urse, G., Chelu, A., Evaluation and completion the design methods of pressure vessels flange joints, Revista de Chimie, vol. 69, no. 8, 2018, p. 1954-1961.

[34] Urse, G., Durbaca, I., Panait, C. I., Some research results on the tightness and strength of flange joints, Journal of Enneering Sciences and Innovation, vol. 3, no. 2, 2018, p. 107 - 130.

[35] EN 1092-1:2018, Flanges and their joints - Circular flanges for pipes, valves, fittings and accessories, PN designated - Part 1: Steel flanges, NSAI Standards, 2018.

[36] Ma, B., Zhu, Y., Jin F., Ding, Q., Guo, X., A lightweight optimal design model for bolted flange joints without gaskets considering its sealing performance, ARCHIVE Proceedings of the Institution of Mechanical Engineers, Part E, Journal of Process Mechanical Engineering, vol. 232, no. 2, 2018, p. 234 - 235. 
[37] Roman (Urse), G., Cercetari referitoare la corelatia dintre rigiditatea, rezistenta si etanseitatea asamblarilor cu flanse plate inelare ale recipientelor sub presiune, Teza de doctorat, Universitatea Politehnica din Bucuresti, 2019.

[38] Roman (Urse), G., Comparative analysis of current international standards for calculations flanges joint with gasket inside the circle location of the bolt holes, Revista de chimie, vol. 71, no. 3, 2020, p. 1 - 8.

[39] Iatan, I.R., Roman (Urse), G., Tomescu, Gh., Chelu, A., Analytical study of thermomechanical strength of assemblies with optional plane flanges. The effect of the flange ring rotation around the median circumference, Revista de Chimie, vol. 71, no. 3, 2020, p. 79 - 89.

[40] Iatan, I.R., Renert, M., Calculul si constructia flanselor cu nervuri, Institul Politehnic Bucuresti, Science Bulletin, Series D, vol. 11, 1978, no. 2, p. 51-60.

[41] Iatan, I.R., Renert M., Botea N., Metoda de calcul pentru flansele cu nervuri tesite, Revista de Chimie, vol. 29, no.7, 1978, p. 678-682.

[42] Iatan, I.R., Cercetari teoretice si experimentale privind constructiile de imbinari cu flanse cu nervuri, Teza de doctorat, Institutul Politehnic din Bucuresti, 1979.

[43] Iatan, I.R., Renert M., Stari de deformatii si de eforturi unitare in inelele flanselor cu nervuri, Revista de Chimie, vol. 32, no. 5, 1981, p. 491 - 497.

[44] Iatan, I.R., Renert M., Cercetari experimentale privind starea de tensiuni in zona cilindrica a constructiilor cu flanse cu nervuri, Studii si Cercetari de Mecanica Aplicata, vol. 44, no. 4, 1985, p. 384 - 395.

[45] Wang, O.Y., Zong, L., Shi J.Y., Bending behavior and design model of bolted flange-plate connection, Journal of Constructional Steel Research, vol. 84, 2013, p. 1 - 16.

[46] Iordache, Gh., Iatan, I.R., Nuca, G., Calculul agrafelor simple, utilizate la imbinarea cu flanse a recipientelor sub presiune, Constructia de Masini, vol. 29, no. 1, 1977, p. 33 - 39.

[47] Iatan, I.R., Filimon, C., Calculul asamblarilor cu flanse si cleme, Revista de Chimie, vol. 42, no. 1-3, 1991, p. $117-121$.

[48] Iatan, I.R., Filimon, C., Calculul asamblarilor cu flanse si cleme, Revista de Chimie, vol. 42, no. 8-9, 1991, p. 443 - 448.

[49] Dekker, J.C., Stikvoort, J.W., Improved design rules for pipe clamp connectors, International Journal of Pressure Vessels and Piping, vol. 81, 2004, p. 141 - 157.

[50] Mogri, M., Deformation and stresses generated on the bolted flange joint assembly and the Grayloc clamp connector at elevated temperatures, Thesis, Carleton University Ottawa, Ontario, 2013.

[51] Tomescu, Gh., Iatan I.R., Criterii de alegere a materialelor fara azbest pentru etansari statice, Constructii de Masini, vol. 55, no. 7 - 8, 2003, p. 78 - 81.

[52] Kurz, H., Auslegung und optimierung von flanschverbindungen mit SMC - Losflanschen und PTFE dichtungen, Dissertation, Universita Stuttgart, Germany, 2014.

[53] Dichtungs - Technik, (Katalog), KLINGER GmbH, 2016, on line la http://www.vteindustrietechnik.de/download/dichtungsplatten/Klinger/KLINGER\%20Katalog_2016_D2.pdf (12.04.2021).

[54] Kirkemo, F., Design of compact flange joints, ASME - PVP 2002, Bolted Flange Connections, 2002, Vancover, British Colombia, Canada.

[55] Deininger, J., Untersuchung des dichtverhaltens von mettallischen profildichttungen für hochdruck-apparate, Dissertation, Technischen Universität München, Germany, 2004.

[56] Diany, M., Azouz, J., Aissaoui, H., Boudaia, H. E., Stresses fields in axial compressed O-ring gasket, The International Journal of Engineering and Science (IJES), vol. 7, no. 9, 2018, p. 60-66.

[57] Joshi, D., Mahadevan, P., Marathe, A., Chatterjee, A., Unimportance of geometric nonlinearity in analysis of flanged joints with metal-to-metal contact, International Journal of Pressure Vessels and Piping, vol. 84, 2007, p. 405-411.

[58] Bertini, L., Beghini, M., Santus, C., Metal to metal flanges leakage analysis, Proceedings of the ASME 2009 Pressure Vessels and Piping Division Conference, PVP, 2009, 2009, Prague, Czech Republic, p. 1 - 10.

[59] Galai, H., Bouzid, H.A., Analytical modeling of flat face flanges with metal-to-metal contact beyond the bolt circle, Journal of Pressure Vessel Technology, vol. 132, 2010, p. 1 - 8.

[60] Beghini, M., Bertini, L. Santus, C., Gughielmo, A., Mariotti, G., Partially open crack model for leakage pressure analysis of bolted metal-to-metal flange, Engineering Fracture Mechanics, vol. 144, 2015 , p. 16 - 31.

[61] Jinescu, V.V., Paunescu M., Etanseitatea asamblarilor cu flanse, Revista de Chimie, vol. 41, no. 11-12, 1990, p. $898-903$.

[62] Paunescu, M., Taca, C.D., Stefanescu, M.F., Flanged joints rigidity of the pressure vessels, Romanian Academy, Modeling and Optimization in the Machines Building Field (MOCM-6), 2000, p. 45 - 51.

[63] Diany, M., Determination de la largeur effective des joints d'etancheite utilisee dans le Code ASME pour le calcul des brides, These, Ecole de Technologie Superieure, Universite du Quebec, Canada, 2005. 
[64] Paunescu, M., Behaviour of non-metallic gaskets in smal and medium pressure conditions, Revista de Chimie, vol. 61, no. 2, 2010, p. 118 - 120.

[65] Haruyama, S., Nurhadiyanto, D., Choiron, A.M., Kaminishi, K., Influence of surface roughness on leakage of new metal gasket, International Journal of Pressure Vessels and PIPING, vol. 111 - 112, 2013, p. 146 - 154.

[66] Omiya, Y., Sawa, T., Stress analysis and sealing performance evaluation of bolted pipe flange connections with smaller and larger nominal diameter under repeated tempartura changes, Proceedings of the ASME 2014, Pressure Vessels and Piping Conference (PVP 2014), Anaheim, California, USA, 2014.

[67] Schaaf, M., Stegie zur verminderung von emissionnen aus flanschverbindungen, Dissertation, Universitat Stuttgart, Germany, 2015.

[68] Nelson, R.N., Prasad S.N., Sealing behavior of twin gasketed flange joints, International Journal of Pressure Vessels and Piping, vol. 138, 2016, p. 45 - 50.

[69] Iatan, I.R., Roman (Urse), G., Considerations about flange with ring gasket. The sealing pressure, Revista de Chimie, vol. 60, no. 11, 2009, p. 119 - 122.

[70] Paunescu, M., Experimental research regarding gaskets durability, International Jornal Fatigue, vol. 28, 2006, p. 1081-1086.

[71] Smolnicki, T., Rusinski, E., Karlinski, J., FEM modelling of fatigue loaded bolted flange joints, Journal of Achievements in Materials and Manufacturing Engineering, vol. 22, no. 1, 2007, p. 69 - 72.

[72] Nechache, A., Bouzid, H.A., Creep analysis of bolted flange joints, International Journal of Pressure Vessels and Piping, vol. 84, 2007, p. 185 - 194.

[73] Nechache, A., Bouzid, H.A., On the use of plate theory to evaluate the load relaxation in bolted flanged joints subjected to creep, International Journal of Pressure Vessels and Piping, vol. 85, 2008, p. 486 - 497.

[74] Couchaux, M., Ryan, I., Hjiaj, M., Stress concentration factor for the fatigue design of tubular flange connections, NSCC, 2009, p. 255-262.

[75] Gordon, P.A., Williams, J., Santiago, D.M., Analytical modeling of the mechanics of re-torque, Proceedings of the ASME 2011, Pressure Vessels and Piping Division Conference (PVP 2011), Baltimore, Marylanda USA, 2011.

[76] Cheng, Y., Zheng, T.X., Yu, Y.J., Xu, M.J., Wang, G.C., Lin, W., Thightness assessment of bolted flange connections the creep effect of gasket, Proceedia Engineering, vol. 130, 2015, p. 221 - 231.

[77] Mourya, K.R., Banerjee, A., Sreedhar, K.B., Effect of creep on the failure probability of bolted flange joints, Engineering Failure Analysis, vol. 50, 2015, p. 71 - 87.

[78] Jinescu, V.V., Fatigue life prediction for simultaneous cyclic loading with blocks of normal stresses and shear stresses, Journal Engineering Sciences and Innovation, vol. 1, no. 1, 2016, p. 1 - 16.

[79] Luyt, B.C.P., Theron, J.N., Pietra, F., Non-linear finite element modelling and analysis of the effect of gasket creep-relaxation on circular bolted flange connections, International Journal of Pressure Vessels and Piping, vol. 150, 2017, p. $52-61$.

[80] ASME PCC-1-2019 - Guidelines for pressure boundary bolted flange joint assembly, The American Society of Mecanical Engineers, New York, USA, 2019.

[81] Kantorovici, B.Z., Osnovi rasceta himiceskih masin i apparatov, G.N.T.I.M.L, Moskva, 1952.

[82] Iatan, I.R., Placi circulare si inelare, gofrate si perforate, Ed. MatrixRom, Bucuresti, 2012.

[83] Iatan, I.R., Enachescu, G.L., Florescu, Gh.P., Solicitari mecanice si termice in placi compozite stratificate, vol. 2, Ed. Matrix Rom, Bucuresti, 2017.

[84]. Jinescu, V.V., Chelu, A., Roman (Urse), G., A method based on the principle of critical energy for calculating flange joints, Revista de Chimie, vol. 71, no. 2, 2020, p.185 - 190.

[85]. Jinescu, V.V., Nicolof, V.I., Panait, C.I., Critical stresses, deterioration and failure criteria for cracked structures, Journal of Engineering Sciences and Innovation, vol. 5, no. 4, 2020, p. 299 - 314.

[86] Jinescu, V.V., Non-propagation crack criteria and fracture criteria in the case of mixed-mod fracture taking into account the deterioration, Journal of Engineering Sciences and Innovation, vol. 6, no. 1, 2021, p. 11 - 30. 